\title{
Optimum Implementation of Information Technology in Elementary Education
}

\author{
Jasna Milički, Ph.D. \\ jasna.milicki@skole.hr \\ Marija Bistrica Elementary School
}

\author{
Ana Sudarević \\ ana.sudarevic1@skole.hr \\ Dubovac at Elementary School in Karlovac
}

Keywords: reading, e-book, Google generation, information-communication technology, elementary school, multitasking

\begin{abstract}
It is well known that reading and writing techniques are learned throughout childhood and that they have a great significance for further development of each individual and the society in general. However, in this day and age children make their first contact with language and script using the widespread digital media. Later in life this will have a negative effect on their ability to recognize letters and start reading. Nowadays Croatian schools are experiencing intensive informatization of educational process. It is expected that modern technology will be used daily, for several hours. On the other hand, we have been witnessing everyday (mis) use of technology by the young people in their free time. The questions then arise: how much time will the students be exposed to the influence of the media on a daily basis, either for educational purposes or for fun? What consequences will this exposure have for them? Numerous researches have shown that overexposure to technology affects cognitive abilities of young people. It is true that young people possess technological skills which they use much more efficiently than the older population, but at the same time they have difficulties assessing or evaluating the sources of information. One of the possible problems is their lack of knowledge about how information is organized or the lack of previous knowledge of a certain field.

As far as texts are concerned, most young people will choose printed ones because they think that learning through electronic media is tiresome. The (in) efficiency of learning from e-books is related to excessive use of hyperlinks and other links that divert attention.

At the beginning of the school year 2019/2020, Croatian schools will introduce curricular reform which will be accompanied by an emphasized use of tablets and digital content. As educational experts, we advocate optimum implementation of media as technology that makes communication easier, but does not condition it. Communication in educational institutions should be mostly oriented towards quality, content of information and critical approach and to a lesser extent towards the possibilities offered by the media as a means of communication.
\end{abstract}


As to the use of multimedia technology for educational purposes, the e-book and e-reading will be related to specific tasks, research, projects and tasks in popular science area. On the other hand, printed books will still be read in free time, for pleasure and for literary needs. The above are the results of our research done on reading e-books in elementary schools in the Republic of Croatia. With this research we have shown that the so-called Google generation still does not like reading online, including the assigned reading at schools. As it turns out, the assumption that the young people who have been surrounded by the new technology since their birth, will likewise be more interested in reading texts in the new media, is in fact wrong, despite favourable technical conditions. They use the internet and the technology for communication and for fun, but rarely for studying.

Therefore, a pilot survey among eighth grade students is about to be conducted. It will show their attitudes and reflections about using more media at the same time (multitasking) and how it affects their studying. It will also show whether the students' attitudes toward e-books and reading has changed.

\section{Introduction}

The intensive development of reading and writing skills which represent the predisposition for further development of an individual, marks the first cycle of formal education of students in the Republic of Croatia just like in other education systems around the world.

As one of the goals of education (Ministry of Science, Education and Sport, 2010) it is mentioned that it was necessary to enable students to acquire basic and specific competences according to the demands of contemporary information-communication technologies and equip them for lifelong learning. The education system in the Republic of Croatia will begin with the implementation of Complete Curricular Reform as one of the first measures of the realization of the Strategy of the Education, Science and Technology at the beginning of the 2019/2020 school year. Following the above, the curricula for all school subjects have been developed, including Computer Science which will be implemented in 2020/2021 school year in grades 1 to 4 of elementary school. This decision is based on recommendations resulting from empirical research, for example, Students' use of Web literacy skills and strategies: searching, reading and evaluating Web information (Kuiper, Volman, \& Terwel, 2008) which suggests teaching web browsing skills from the earliest school age, that is, before children start browsing the internet alone thus creating their own, often inadequate, browsing habits and use of internet sources. We cannot yet comment on the results of such an approach to education, even with contradictory public opinions on the matter. According to some, this presents the possibility of acquiring the specific knowledge skills and attitudes which would support all other subjects and areas of study, while the others warn of its danger to cause neglect of the development of basic skills - writing, graphomotor skills, reading, speech, etc. We should pay attention to ethical dimension, because contemporary technology influences and shapes the youth, thus the society as a whole (Bilić, 2015).

\section{Google Generation}

The observed youth population, involved in formal education, belongs to Google generation, in literature also known as generation $V$, generation $M$ and generation $C$, also Net generation or Trophy generation, according to their connection with technology which they often and gladly use on a daily basis, mostly for fun and communication with their peers, in form of playing video games, using social networks or browsing the internet content, often searching for information about sports, or humorous or fun content and less likely for the information on health, travel, religion and alike (Selwyn, 2009). Hence, with the elementary school students, it has been determined that they daily spend two hours more in front of screens than outdoors and have easier time solving virtual problems (e.g. in Video games) compared to

International Association of School Librarianship

https://iasl-online.org 
those in real life (Foretić et al., 2009; according to Bilić, 2016). Lack of sleep due to using digital devices late at night is another problem leading to concentration and behavioral issues and failure in fulfilling school tasks (Bilić, 2016). Furthermore, this connection with technology is often passive, lonely and sporadic both at home or in school (Livingstone, 2009; according to Selwyn, 2009), and it includes passive consumption of knowledge instead of active content creation (Selwyn, 2009).

On the other hand, in the analysis of the way Google generation students learn, they are called Homo zappiens contrasted to Homo sapiens, that is, the older generations. Among other characteristics, Homo zappiens are described as skilled and prone to the digital. Their everyday activities, including learning, are marked by speed, multitasking, searching for information of momentary relevance and wide attention span (Bilić, 2016). This results in troubling characteristics like inefficient learning, lower efficiency due to "juggling" between different tasks; lack of persistence, patience and concentration due to "floating attention" and urge to find the solution as quickly as possible. This is especially obvious in searching for and using information for learning purposes. Namely, the research results on the way of processing and use of information indicate that these are mostly superficial interactions focused on the quantity rather than qualitative data interpretation and critical analysis essential for deep and meaningful learning (Lasić-Lazić, Špiranec, \& Banek Zorica, 2012).

Another characteristic of this generation is, so called, "culture of disrespect" (Bugeja, 2006; according to Selwyn, 2009). It denotes the effort of young people to weaken the influence of older generations as well as formal institutions, such as schools, libraries, museums (Selwyn, 2009). Regarding libraries, it is obvious in the fact that over $90 \%$ of young people consider internet browsers ideal for their purposes, while $30 \%$ less consider libraries, either online or physical, equally useful. This is best illustrated by the attitude towards library resources. They are considered more accurate and credible than internet browsers, but lacking in terms of expected speed, ease of use and adequacy (Berk, 2009). Likewise, some studies show that young people distinguish the use of modern technology in institutions like schools or libraries and in their time off. Namely, they are not keen to use them for work (learning) (Lohnes \& Kinzer, 2007; according to Selwyn, 2009). This is the signal for schools and libraries, or librarians as information experts, to empower their role in the context of supporting young people in their access to digital technology in the sense of hardware and software availability. There will always be occasions when students will need directions on how to work with modern technology and online tools, possibly because of lack of experience, confidence or motivation (Selwyn, 2009). Therefore, librarians and teachers can remain the authority for students in education, retrieving information and guiding activities connected with technology while teaching students corresponding strategies of their use (Young \& Muller, 2009; according to Selwyn, 2009).

We conduct more research on students today than ever before - how their brain and intelligence function, how they learn, how to teach them more successfully, what is the impact of technology on learning, etc., but nevertheless we witness their lack of motivation and interest for the subject matter and learning (Berk, 2009). One of the possible solutions for positive change can be the accent on individual learning according to specific, individual possibilities and needs, but also in cooperative learning, accompanied with the use of digital technology. Furthermore, as opposed to the conventional orientation to the subject matter of individual subjects, it is recommended to focus on a wider theme and to present students with the challenge of creative problem solving (Veen, 2007). The Curricular Reform addresses this in cross-curricula topics and correlations.

\section{Methodology}

International Association of School Librarianship

https://iasl-online.org 
The research was conducted on a sample of 136 students - 64 girls (47.1\%) and 72 boys $(52.9 \%)$ - grade 8 students, 13 or 14 years of age from four elementary schools in the Republic of Croatia: Elementary school Dubovac, Karlovac; Elementary school Marija Bistrica, Marija Bistrica; Elementary school Lasinja, Lasinja; Elementary school Oroslavje, Oroslavje. They are all part of the so-called Google generation, i.e. young people who have been surrounded by technology since their birth and they use it daily for different purposes and in different ways. Accordingly, the research hypotheses are determined:

- young people are apt to use multitasking

- playtime decreases study time and that directly affects the academic success

- overuse of digital media leads to lesser academic success

The research was conducted through an online questionnaire with two groups of questions: school and free time, and media. All questions were closed ended. Students were able to fill in the questionnaire on their own in one-month period during the months of May and June 2019.

The method of synthesis of collected data gives possible guidelines for librarians to act with the purpose of optimal implementation of modern technology, both for learning purposes and to use in their free time.

\section{Results}

The students of the Google generation, as we had predicted, are technically well equipped; most (97.1\%) own their personal smartphone, and $94.9 \%$ own a computer. It was a pleasant surprise to find out that more students have their own sports equipment (73.5\%) than a gaming console such as PlayStation or alike (53.7\%).

Such an exposure to the digital media suggests a great quantity of time spent on it and that can be related to academic success or failure.

$30.1 \%$ of the students claim to have extended the time they spend playing video games gradually during the period from grade 5 to grade 7, (see Figure 1), and they estimate the same regarding their peers - they think that $72.8 \%$ of them spend more time playing video games as they grow older.

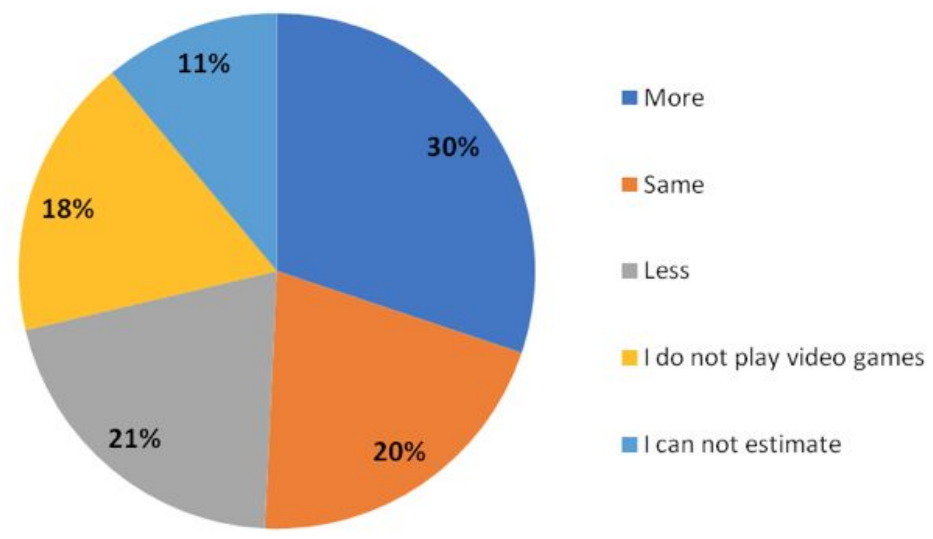

Figure 1: The estimate of the extent of time spent on playing video games during the period from grade 5 to grade 7.

On the other hand, it can be observed that in the same timeframe, during the period from grade 5 to grade 7, the students' average marks drop (see Figure 2). While in grade 5 there were $47.7 \%$ excellent students, $39.7 \%$ had very good average marks and $11.09 \%$ good marks, and in grades 6 and 7 we recorded a drop in 
the number of students with excellent marks, by $4.4 \%$, and $11 \%$ respectively. At the same time there is an increase in the percentage of the very good and good average marks; in grade 6 both grow by $2.2 \%$, followed by $7.3 \%$ increase in very good average marks, and $2.9 \%$ in good average marks in grade 7 .

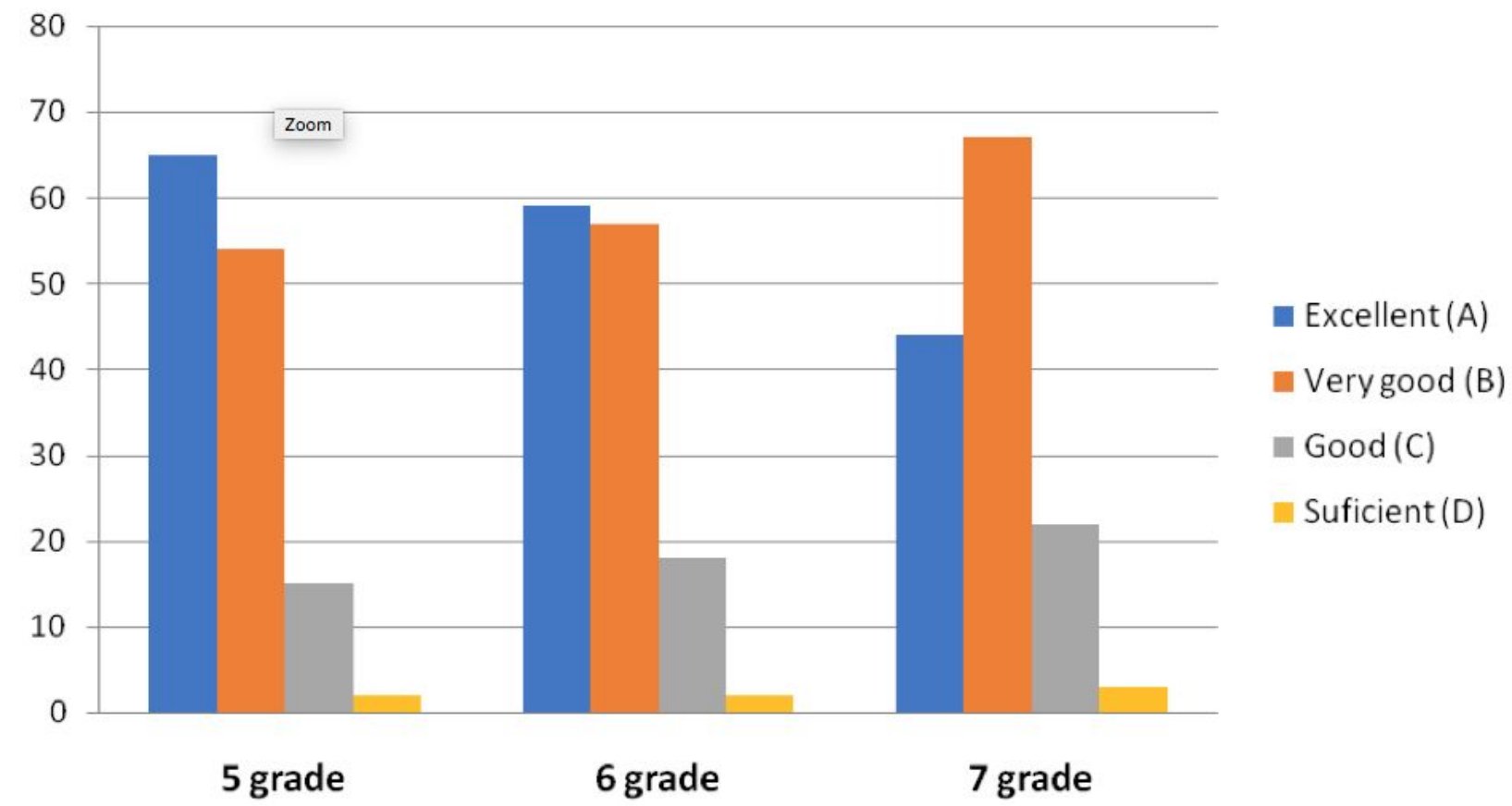

Figure 2: Average marks of students in grades 5 to 7

The next influential factor for academic success could be the time dedicated to studying, as opposed to time spend with digital media. Students on average study between one hour (26.5\%) and two hours (25\%), while $25.7 \%$ study for less than an hour a day. On the other hand, most often students spend three to four hours a day $(35.2 \%)$ on digital media, or five to six hours a day $(26.4 \%)$, while $22.7 \%$ of students are using digital media for more than six hours a day. On top of this, it is important to mention that $39 \%$ of participants often use more than one device at a time (so called multitasking) while doing their homework, $27.2 \%$ do it sometimes, $23.5 \%$ do it every time (see Figure 3). Regarding frequency, the differences by gender are minimal: boys do it more frequently by $5 \%$ to $9 \%$. Only $10.3 \%$ of students never use more than one type of media at the same time, this time in favor of the girls, $12.5 \%$ of the girls never use more than one media type at a time while doing homework, while $8.3 \%$ of the boys claim the same. 


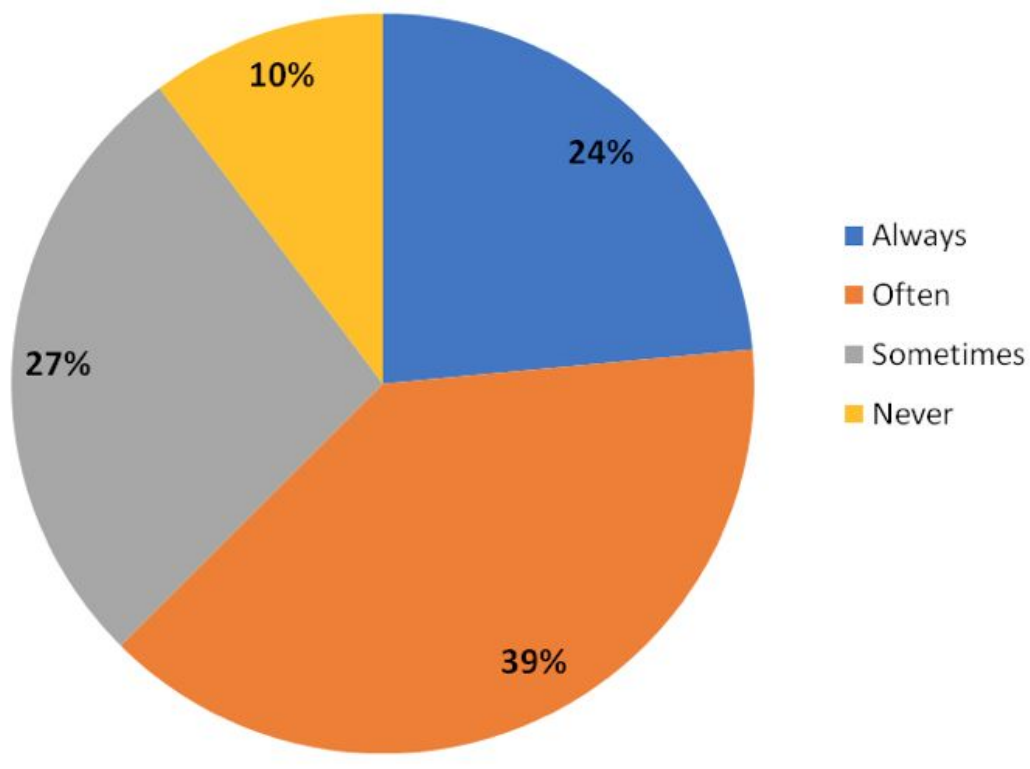

Figure 3: Frequency of using various media while studying

More than a half of the participants $(60.3 \%)$ state digital sources are more valuable than the printed ones in the context of doing schoolwork (see Figure 4). However, there are differences between boys' and girls' opinions on this matter: $76.3 \%$ of the boys value the digital sources more, while $57.8 \%$ of the girls prefer printed sources.

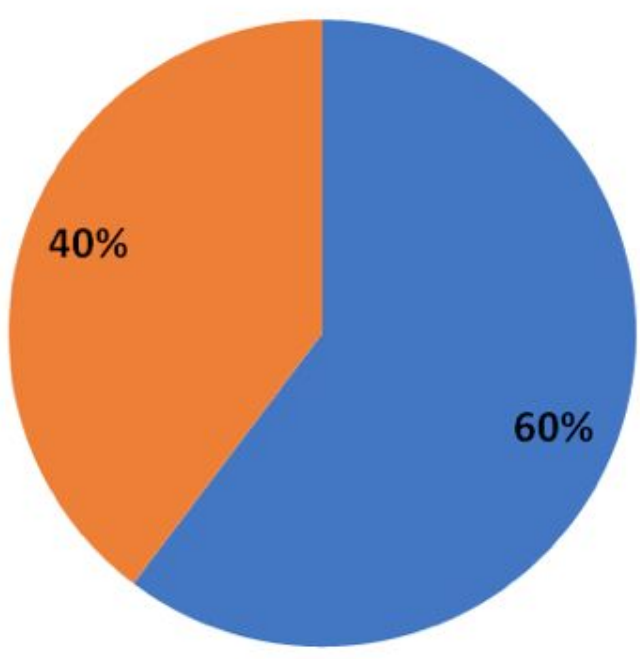

\section{E-resources}

Printed resources

Figure 4: Students find e-resources more valuable compared to the printed sources in the context of studying

We should consider the time of the day when the media are used: one third of the students uses media until after midnight (36\%) while the rest use it until midnight $(24.3 \%)$ or $11 \mathrm{PM}(22.8 \%)$. Therefore, it is not surprising that even $38.2 \%$ of the participants sometimes feel tired as soon as they arrive at school, 
and $32.4 \%$ feel fatigued almost every day at the beginning of the school day. Furthermore, from results it can be observed that the girls feel tired almost every day (39\%) or sometimes $(34.3 \%)$, while the boys mostly feel tired sometimes when they arrive at school (41.6\%) as opposed to every day $(29.1 \%)$. Looking at the differences by gender the results show that all the girls claim that they are tired at least sometimes when they arrive to school, while only $2.7 \%$ of the boys are always sufficiently rested.

\section{Discussion}

The research has shown the correlation between time spent with the media, which increases with age, and the academic success and failure of the students.

Comparing the results of this research with results of the research conducted in 2017 (Milički \& Sudarević, 2018) among the students in grades 6 and 8, we can see certain differences, for which we cannot claim are for the better. According to the results from 2017, students were using digital media mostly for watching videos, communication on social media and chatting, and rarely for reading news outlets and searching for education-related information.

Over $60 \%$ of the students stated at the time they prefer reading books in a printed format than in electronic one when it comes to literary texts, more precisely assigned reading, while citing advantages such as easier focus on the content, being less tiring on the eyes, easier time finding their way through the text and alike. In other words, as the main disadvantage of reading from the screen they singled out tiring of the eyes, more difficult comprehension of the content, and only after that economic reasons, such as obtaining appropriate application or problems with the internet connection (Milički \& Sudarević, 2018). Thus, they focused more on physical characteristics of the media. Today, more than a half of the participants $(60.3 \%)$ find electronic sources more valuable compared to the printed ones in the context of completing schoolwork. However, the opinions of boys and girls around this question differ: $76.3 \%$ of the boys consider the electronic sources more valuable, while $57.8 \%$ of the girls prefer printed sources. Here we did not address the characteristics of the media themselves.

Considering everything stated above we need to question the students' capability to choose a reliable electronic source and content as they mostly use the internet for fun and communicating with friends (see Figure 5) as reflected in the results of the previously mentioned research by Milički and Sudarević (2018) as well as other references confirm (Selwyn, 2009). 


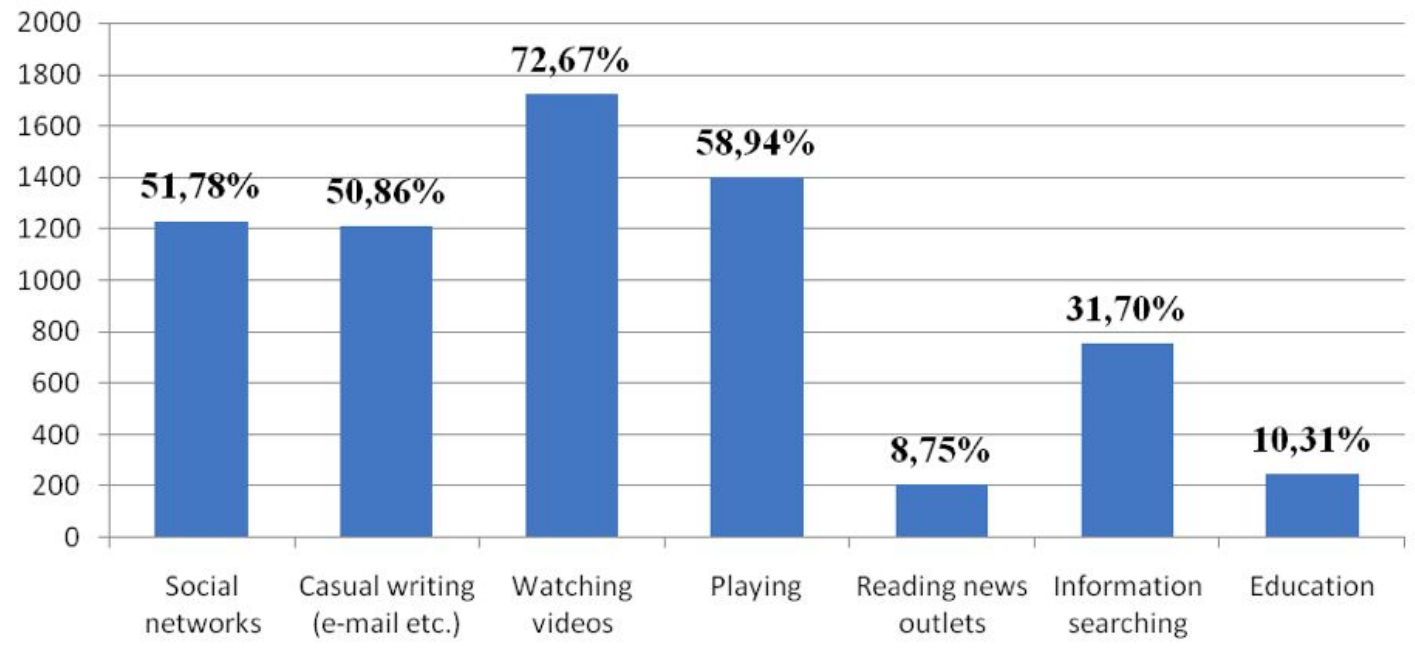

Figure 5: Main reasons for using digital media

This research also confirmed that children of this age (grade 8 students) practice multitasking, i.e. perform several actions parallel to doing homework which can directly cause decline of academic success. However, those habits could be directed and used for educational purposes through project work and research tasks. Such approach includes teamwork and collaboration which is completely in sync with students' need for networking, connectivity, constant communication with friends and their surroundings, which can be done simultaneously or not, allow for fast access to information, but all of this with guidance and help from a mentor (teacher, librarian). Social networks are maybe not the best solutions for the students of this age, but if they learn to use them as extended educational tools, they could be helpful later in virtual world in the process of creating new content and knowledge constructs.

The role of school regarding the electronic media is to determine the best measure of implementation of the information-communication technology, which is age appropriate and suits the intellectual level of the students while considering the needs of the Google generation. School is the one to guide the students towards reliable information by filtering the best sources and by offering the appropriate tools. In order to be successful in these efforts teachers and other school staff must be trained for this methodology. School librarians provide the best starting point for the execution of these changes by teaching information and media literacy. 


\section{Conclusion}

Librarians suggest, in order to fully utilize the potential of the educational digital sources, to encourage students to take advantage of the reading applications, as well as the portals that offer electronic content, so they could be more familiar with all their capabilities. We should not ignore the powerful roll of social networks which we cannot avoid but can use in an interactive context of the educational tasks. And precisely because of the communication role, we cannot leave students on their own while they are coping with electronic texts and books because their failed attempts could lead to frustration and alienation from modern educational technologies.

It is our opinion that educational multimedia technologies, e-books and e-reading will become more connected with specific tasks, research, projects and homework connected to applied sciences, while the printed book will never lose its position which it has in leisure reading, reading for pleasure and other literary needs.

Thus, the preferences of Google generation students are changing. Accordingly, the approach to teaching is changing as well. Along with the teachers, the librarians must adjust and adapt their methodology, but in a way so they act not only in the educational but also in the nurturing domain. Therefore, we see the role of the librarians through:

- teaching information and media literacy

- encouragement of reading literacy and critical thinking

- encouragement of reading in different formats

- prevention of negative impact of the media

The educational system in the Republic of Croatia is undergoing changes. We are yet to see whether the programs have rationally included information-communication technology through all educational cycles keeping in mind the demands of the Google generation, whether the teachers and librarians are sufficiently equipped and empowered to change primarily themselves, and then with adapted methods and strategies to lead the youth through saturated world of information.

The students who participated in this research will continue with their formal education in the next school year in high schools - academic prep and trade schools. Whatever they choose they will be part of The Curricula Reform up to the end of their secondary education. It remains to be seen if they are sufficiently ready for the announced changes.

\section{REFERENCES}

Berk, R. A. (2009). Teaching Strategies for the Net Generation. Transformative Dialogues: Teaching \& Learning Journal, 3(2), 1-24. Retrieved from https:/www.kpu.ca/td

Bilić, V. (2016). The Net-generation Methods of Learning, Online Activities and Upbringing Outcomes. Croatian Journal of Education, 18(Sp.Ed.1), 259-277. https://doi.org/10.15516/cje.v18i0.2065

Kuiper, E., Volman, M., \& Terwel, J. (2008). Students' use of Web literacy skills and strategies: searching, reading and evaluating Web information. Information Research, 13(1) paper 351. Retrieved from http://www.informationr.net/ir/ 
Lasić-Lazić, J., Špiranec, S., \& Banek Zorica, M. (2012). Izgubljeni u novim obrazovnim okruženjima pronađeni u informacijskom opismenjivanju. Medijskaistraživanja, 18 (1), 125-142. Retrieved from http://www.mediaresearch.cro.net/hr/o-casopisu

Milički, J., \& Sudarević, A. (2018). Ograničava li medij čitanje: rezultati istraživanja iskustava i stavova učenika šestih i osmih razreda prema e-lektiri. In G. Braim Vlahović \& A. Granić (Eds.). $X X X$. Proljetna škola školskih knjižničara RH: Tradicija i suvremenost u radu školskog knjižničara, Proceedings (pp. 288-303). Retrieved from https://www.azoo.hr

Ministarstvo znanosti, obrazovanja i športa. (2010). Nacionalni okvirni kurikulum za predškolski odgoj $i$ obrazovanje te opće obvezno i srednjoškolsko obrazovanje. Zagreb: Ministarstvo znanosti, obrazovanja i športa.

Selwyn, N. (2009). The digital native - myth and reality. Aslib Proceedings, 61(4), 364-379. https://doi.org/10.1108/00012530910973776

Veen, W. (2007). Homo Zappiens and the Need for New Education Systems. Retrieved from https://www.semanticscholar.org

Jasna Milički

Biography

Jasna Milički graduated from a high school in Zagreb. In 2008 she defended her Master's degree, and in 2014 her Doctoral thesis at the Department of Communication and Information Sciences. Jasna works at Elementary School Marija Bistrica as a school librarian. In 2011 she advanced to the position of a library adviser. She continued to cooperate with the Agency for Education on matters of professional training of school librarians. The area of her professional interest is development and improvement of school libraries, especially in the field of education based on school and library curricula.

Ana Sudarević

Biography

Ana Sudarević works as a school librarian at the Dubovac Elementary School in Karlovac with a vocation of a consultant staff associate. Since 2006 she has been a head of the County Expert Council of Librarians from elementary and secondary schools of the Karlovac County. The special area of her interest is educational work with emphasis on modern technologies. Upon this particular topic she has had many presentations at expert meetings and conferences in Croatia and abroad, has conducted numerous workshops and published articles in respectable journals and proceedings. At the Center for Continuous Professional Training of Librarians she is a co-leader of the New Technologies in the Education of Children and Teens course. 